\title{
Electrochemical Property of Ru-Mn-AC Multi-Element Composite Electrode Materials
}

\author{
Zhang Li, Song Jinyan, Zou Jiyan \\ Dalian University of Technology, Dalian 116024, China
}

\begin{abstract}
In order to improve the performances of electrode materials for super-capacitors, multi-element composite electrodes were prepared using $\mathrm{RuO}_{2}$ and $\mathrm{MnO}_{2}$ as active materials, and active carbon as basic materials. Good electrochemical performances of the composite electrodes were confirmed by cyclic voltammetry, galvano static charge/discharge and ac impedance measurements. When the content of $\mathrm{MnO}_{2}$ is $20 \mathrm{wt} \%$ in composite electrode materials, the specific capacitance of $\mathrm{MnO}_{2} / \mathrm{AC}$ composite electrodes can reach $128 \mathrm{~F} / \mathrm{g}$ with a resistance of $2.62 \Omega$. When the contents of $\mathrm{RuO}_{2}$ and $\mathrm{MnO}_{2}$ are separately $20 \mathrm{wt} \%$ in composite electrode materials, the specific capacitance of $\mathrm{RuO}_{2} / \mathrm{MnO}_{2} / \mathrm{AC}$ composite electrodes can reach $266 \mathrm{~F} / \mathrm{g}$ with a resistance of $0.86 \Omega$ almost without any change of capacitance during 1500 cycles of charge/discharge. It is indicated that the multi-factor composite electrodes with $\mathrm{RuO}_{2} / \mathrm{MnO}_{2} / \mathrm{AC}$ are ideal electrode materials for super-capacitors.
\end{abstract}

Key Words: $\quad$ super-capacitor; composite electrodes; $\mathrm{RuO}_{2} ; \mathrm{MnO}_{2}$; specific capacitance

Supercapacitor has been recognized as a promising device exhibiting high power and energy density characteristics with long cycle life for energy storage and management in future power sources, such as pulse source and UPS. Recently, the studies of electrode materials that generally would determine the performance of supercapacitor have been focused on the synthesis of composite materials and nano materials and the improvement of impedance and frequency properties of supercapacitor. ${ }^{[1 \sim 3]}$ Active carbon (AC) is a favored choice for electrode materials from their accessibility and low cost. However, due to the high resistance, their usage is rather limited. ${ }^{[4]}$ One approach to enhance the performance of electrodes is to add active materials (such as $\mathrm{RuO}_{2} \cdot x \mathrm{H}_{2} \mathrm{O}$ and $\mathrm{MnO}_{2}$ ) into $\mathrm{AC} .^{[5,6]}$ In this work the composite electrodes composed of the $\mathrm{AC}$, $\mathrm{RuO}_{2} \cdot x \mathrm{H}_{2} \mathrm{O}$ and $\mathrm{MnO}_{2}$ are investigated.

\section{Experimental}

\subsection{Electrode material preparation}

$0.3 \mathrm{~mol} / \mathrm{L} \mathrm{NaOH}$ solution was slowly dropped into the stirred $0.1 \mathrm{~mol} / \mathrm{L} \mathrm{RuCl}_{3} \cdot x \mathrm{H}_{2} \mathrm{O}$ solution until $\mathrm{PH} \approx 7$. Then, the precipitates were found after sedimentation, and then washed with distillated water for several times. Finally, amorphous hydrous ruthenium oxide powders were formed by drying at $150{ }^{\circ} \mathrm{C}$ for $10 \mathrm{~h}$ in air. ${ }^{[7]}$

For $\mathrm{MnO}_{2}$ synthesis, $0.17 \mathrm{~mol} / \mathrm{L} \mathrm{KMNO}_{4}$ solution was added slowly into the $0.15 \mathrm{~mol} / \mathrm{L} \mathrm{Mn}\left(\mathrm{CH}_{3} \mathrm{COO}\right)_{2}$ solution and kept stirring vigorously for $6 \mathrm{~h}$ using PEG400 as the dispersant in this reaction. The products after sedimentation were washed with distillated water for three times and then with absolute alcohol for the last time. These clean precipitates were dried at $110{ }^{\circ} \mathrm{C}$ to yield the amorphous manganese oxide powder of dark brown colour. ${ }^{[8]}$

\subsection{Electrode preparation}

The AC well-mixed with the active material $\left(\mathrm{MnO}_{2}\right.$ and $\mathrm{RuO}_{2} \cdot x \mathrm{H}_{2} \mathrm{O}$ ) in special mass ratios, as seen in Table.1, was ground with 5\% PTFE in agate mortar and rolled into a film with a thickness of $0.2 \mathrm{~mm}$, then pressed on Ta current collector. The size of the electrodes was $1 \mathrm{~cm} \times 1 \mathrm{~cm}$. The obtained electrodes were marked as $1 \# \sim 6 \#$ with different parameters as Table 1, respectively.

\subsection{Electrochemical experiment}

Received date: August 20, 2008

Foundation item: Supported by National Natural Science Foundation of China (50577075)

Biography: Zhang Li, Associate Professor, Department of Electrical and Electronics Engineering, Dalian University of Technology, Dalian 116023, P. R. China, Tel: 0086-411-84707894, E-mail: zhangli379@sohu.com.

Copyright (C) 2009, Northwest Institute for Nonferrous Metal Research. Published by Elsevier BV. All rights reserved. 
Table 1 Performance parameters of composite electrodes

\begin{tabular}{ccccc}
\hline \multirow{2}{*}{ Sample } & $\begin{array}{c}\mathrm{C}: \mathrm{Mn}: \mathrm{Ru}, \\
\omega / \%\end{array}$ & $\begin{array}{c}\mathrm{C}_{\mathrm{p}} / \\
\mathrm{F} \cdot \mathrm{g}^{-1}\end{array}$ & $\begin{array}{c}\mathrm{ESR} / \\
\Omega\end{array}$ & $f / \mathrm{Hz}$ \\
\hline $1 \#$ & $100: 0: 0$ & 90 & 3.5 & 37110 \\
$2 \#$ & $40: 60: 0$ & 95 & 2.4 & 37110 \\
$3 \#$ & $60: 40: 0$ & 117 & 2.57 & 29390 \\
$4 \#$ & $80: 20: 0$ & 128 & 2.62 & 28900 \\
$5 \#$ & $70: 20: 10$ & 130 & 1.91 & 37110 \\
$6 \#$ & $60: 20: 20$ & 266 & 0.86 & 37110 \\
\hline
\end{tabular}

The electrochemical measurements were performed by means of an electrochemical analyzer system, CHI660A, in $30 \% \mathrm{H}_{2} \mathrm{SO}_{4}$ solution at room temperature.

Cyclic Voltammetry (CV) was tested in a three-electrode cell assembly using a given electrode as the working electrode, a saturation calomel as the reference electrode and a Pt wire as the counter electrode in the potential range of -0.6 to $+0.4 \mathrm{~V}$ at $2 \mathrm{mV} / \mathrm{s}$.

Impedance spectroscopy and constant current (charge/discharge) measurements were carried out with the system of two same composite electrodes separated by a separator. Impedance analyzer was made over the frequency range from $10 \mathrm{kHz}$ to $0.1 \mathrm{~Hz}$ with an ac signal of $5 \mathrm{mV}$. The charge-discharge curves were obtained at 2 and $20 \mathrm{~mA}$ in the potential range of 0 to $1 \mathrm{~V}$.

\section{$1.4 \mathrm{X}$-ray diffraction (XRD)}

$\mathrm{XRD}$ analysis was performed with $\mathrm{Cu} \mathrm{K} \alpha$ radiation $(0.154060 \mathrm{~nm})$ at $2 \theta=20^{\circ} \sim 100^{\circ}$

\section{Results and discussion}

\subsection{Cyclic voltammetry measurements}

Curves shown in Fig.1 represent the cyclic voltammograms of the composite electrodes prepared in this work. The symmetric curves have good reversibility from -0.4 to $+0.6 \mathrm{~V}$, indicating typical capacitive behavior. From the comparison of curve $1 \#$ (pure $\mathrm{AC}$ ) with $4 \#$ ( $\mathrm{AC}$ with $20 \mathrm{wt} \% \mathrm{MnO}_{2}$ ), better capacitive response is found on curve $4 \#$. But increasing the amount of $\mathrm{MnO}_{2}$ from $40 \mathrm{wt} \%$ to $60 \mathrm{wt} \%$, the capacities instead decrease as shown in curve $3 \#$ and $2 \#$. The result reveals that the proper content of $\mathrm{MnO}_{2}$ in $\mathrm{AC}$ materials can improve the specific surface and capacitance of composite electrode materials. Moreover, the use of $\mathrm{RuO}_{2} \cdot x \mathrm{H}_{2} \mathrm{O}$ in composite electrodes of $\mathrm{AC}$ with $\mathrm{MnO}_{2}$ powders has obviously increased the capacity. The curve $5 \#$ and $6 \#$ exhibit that the capacities are both larger than that of curve $1 \# \sim 3 \#$ with increasing the amount of $\mathrm{RuO}_{2} \cdot x \mathrm{H}_{2} \mathrm{O}$, especially the curve 6\#. Due to the high specific surface of $\mathrm{AC}$, the active material particles $\left(\mathrm{RuO}_{2} \cdot x \mathrm{H}_{2} \mathrm{O}\right.$ and $\left.\mathrm{MnO}_{2}\right)$ were compounded into the surface and inner pores of $\mathrm{AC}$, making easier contact between the active material and the electrolyte. ${ }^{[9]}$ It reveals that the capacitance of composite electrodes is consisted of the $\begin{array}{lllllllllll}\mathrm{d} & \mathrm{o} & \mathrm{u} & \mathrm{b} & \mathrm{l} & \mathrm{e} & \mathrm{l} & \mathrm{a} & \mathrm{y} & \mathrm{e} & \end{array}$

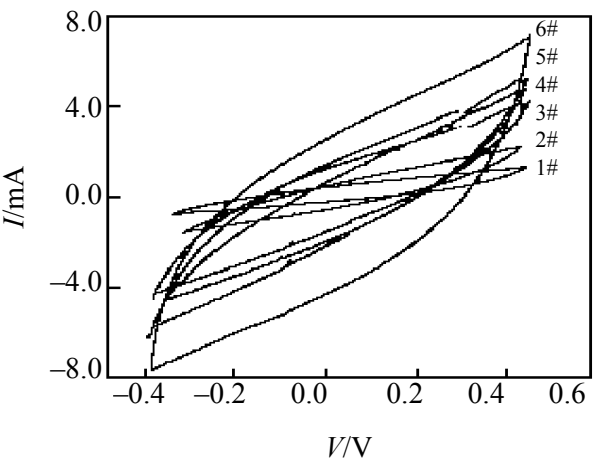

Fig.1 CV curves of composite electrodes

capacitance of active carbon and pseudo capacitance of active material. Thus, the double layer capacitive characteristic of AC and the cost performance can be significantly improved by the combination of pseudo capacitive of $\mathrm{RuO}_{2} \cdot x \mathrm{H}_{2} \mathrm{O}$ and $\mathrm{MnO}_{2}$.

\subsection{Impedance measurements}

Fig.2 shows the Nyquist plots of the composite electrodes. The results reveal that the ESR and frequency responses $f$ are influenced by the amount of the active materials. It can be observed that the ESR decreases but $f$ increase with increasing the amount of $\mathrm{MnO}_{2}$ from the comparison of curve 2\# with 4\#, indicating that the impendence and frequency characteristic were enhanced, as listed in Table 1. The phenomenon is attributable to the distance decrease of electron transfer and the enhancement of electrode conductivity and electron transfer rate when the particles of active carbon are in good contact with the active oxide. The resistance of electrodes composed of $\mathrm{AC}, \mathrm{RuO}_{2} \cdot x \mathrm{H}_{2} \mathrm{O}$ and $\mathrm{MnO}_{2}$ after increasing the amount of $\mathrm{RuO}_{2} \cdot x \mathrm{H}_{2} \mathrm{O}$ was improved from 1.91 to $0.86 \Omega$ as seen in curve $5 \#$ and $6 \#$. It indicates that the hydrous ions of $\mathrm{RuO}_{2} \cdot x \mathrm{H}_{2} \mathrm{O}$ has resulted in the ions of electrolyte into the bulk electrodes, not only shortening the diffusion pathway of electrolyte, but accelerating the reversible redox reaction. ${ }^{[10,11]}$

\subsection{Constant current measurements}

Based on the results and discussion of 3.1 and 3.2, sample electrode $6 \#$ that has larger capacity and lower resistance is a suitable material for supercapacitors. The charge-discharge curves measured at 2 and $20 \mathrm{~mA}$ for 6 \# electrodes are shown in Fig.3, indicating that it has a linear characteristic of charge-discharge rate with current. In addition, its stability has been confirmed from the cycling performance of specific capacitance as shown in Fig.4. Note that the specific capacitance $C_{P}$ increases initially, reaches a maximum after dozens of cycles that due to the activation reaction of the active material $^{[12]}$, and then is much more stable in the following 1500 cycles.

The result implies that the electrode can be operated with acceptable stability. The specific capacitance can be estimated from the following equation: 


$$
C_{P}=\frac{4 i}{m \mathrm{~d} V / \mathrm{d} t}
$$

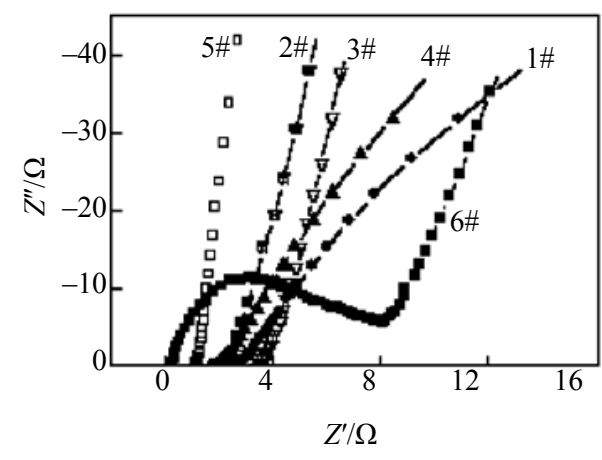

Fig.2 Nyquist plots of composite electrodes

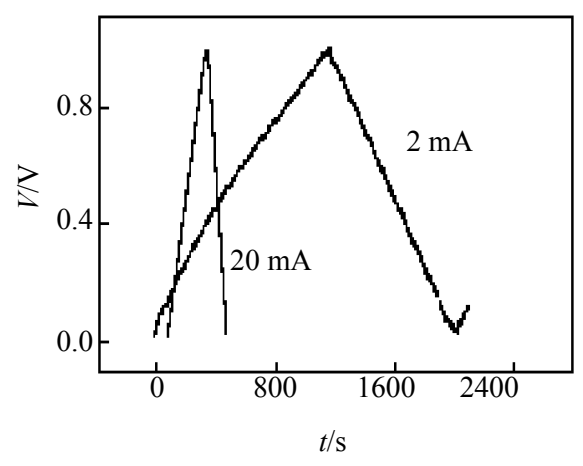

Fig.3 Charge/discharge curves of supercapacitor

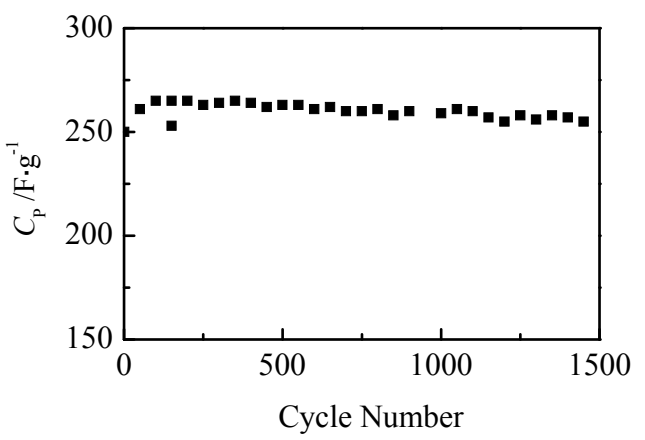

Fig.4 Cycling performance of supercapacitor

where $C_{\mathrm{P}}$ is the specific capacitance for a single electrode in $\mathrm{F} / \mathrm{g}, i$ is the discharge current in $\mathrm{A}, \mathrm{d} V / \mathrm{d} t$ is the rate of charge potential in $\mathrm{V} / \mathrm{s}$, and $m$ is average mass of the electrode in $\mathrm{g}$. The values of specific capacitance were deduced to be 90,95 , $117,128,130$ and $266 \mathrm{~F} / \mathrm{g}$, respectively, as listed in Table1.

\section{$2.4 \mathrm{X}$-ray diffraction}

The typical XRD patterns of composite electrodes 1\# 3\# are shown in Fig.5, respectively. Comparing the curves, it is shown that there is no influence of active oxide adding into the $\mathrm{AC}$ on the crystal structure and peak intensity. The results show that the structures of $\mathrm{RuO}_{2} \cdot x \mathrm{H}_{2} \mathrm{O}$ and $\mathrm{MnO}_{2}$ both are amorphous.

\subsection{Effect of mass ratios on the material characteristics}

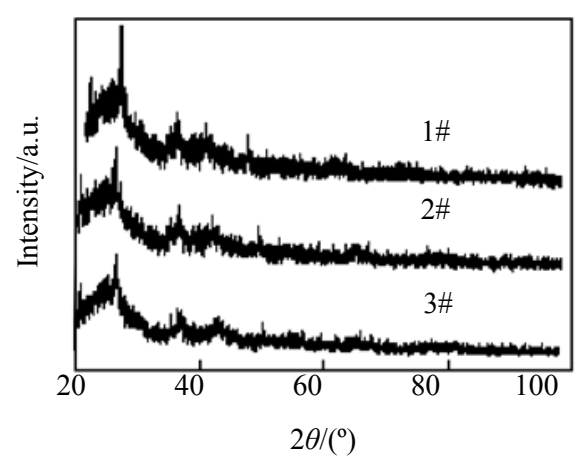

Fig.5 XRD patterns of composite electrodes

The specific capacitance and resistance of the composite electrode of $\mathrm{AC}$ with $20 \mathrm{wt} \% \mathrm{MnO}_{2}$ are both large, and decreased with increasing the amount of $\mathrm{MnO}_{2}$. This might be the reason that the redundant particles of $\mathrm{MnO}_{2}$ cover the surface of active carbon to block the pores on the surface, decreasing the efficient specific surface and the utilization of the double layer capacitance formed in the porous structure. Moreover, although $\mathrm{MnO}_{2}$ as transition metal oxide has lower conductivity, the amorphous $\mathrm{MnO}_{2}$ particles adsorbed on the surface of AC have the positive effect to electric charge so as to improve the conductivity of the composite. The capability and impedance characteristics are further enhanced by mixing $\mathrm{RuO}_{2} \cdot x \mathrm{H}_{2} \mathrm{O}$ into the composite material of $\mathrm{AC}$ with $\mathrm{MnO}_{2}$. Note that the specific capacitance and resistance can be significantly improved by adding $\mathrm{RuO}_{2} \cdot x \mathrm{H}_{2} \mathrm{O}$ into the composite electrode materials with a content of $10 \mathrm{wt} \%$. But the specific capacitance and resistance would increase and decrease, respectively, when the content of $\mathrm{RuO}_{2} \cdot x \mathrm{H}_{2} \mathrm{O}$ is up to $20 \mathrm{wt} \%$. Of course, the increase of $\mathrm{RuO}_{2} \cdot x \mathrm{H}_{2} \mathrm{O}$ amount would increase the cost of electrode materials, and decrease the ratio of capacity to cost.

\section{Conclusions}

The multi-element composite electrodes composed of $\mathrm{RuO}_{2} \cdot x \mathrm{H}_{2} \mathrm{O}, \mathrm{MnO}_{2}$ and active carbon have a promising capability and stable capacitance of 128 and $266 \mathrm{~F} / \mathrm{g}$ for $\mathrm{AC} / \mathrm{MnO}_{2}$ and $\mathrm{AC} / \mathrm{MnO}_{2} / \mathrm{RuO}_{2} \cdot x \mathrm{H}_{2} \mathrm{O}$, respectively, up to 1500 cycles. But the performances of electrodes are affected by the element mass ratios of the composite electrode materials. The best performance is obtained at mass ratio 3:1:1 of $\mathrm{AC}, \mathrm{MnO}_{2}$ and $\mathrm{RuO}_{2} \cdot x \mathrm{H}_{2} \mathrm{O}$. The double layer and pseudocapacitance of the composite electrodes have the complementary advantages to improve the performance of the electrodes.

\section{References}


1 Lin C, Ritter J A, Popov B N. J Electrochem Soc[J], 1998, 145: 4097

2 Emmenegger C, Mauron P, Sudan P et al. J Power Sources[J], 2003, 124: 321

3 Cao F, Parkash J. J Power Sources [J], 2001, 92: 40

4 Zhang Q W, Zhou X, Yang H S. J Power Sources[J], 2004, 125: 141

5 Wang Xiaofeng(王晓峰), Wang Dazhi(王大志), Liang Ji(梁吉). J 1norg Chem(无机化学学报)[J], 2003, 2(19):137

6 Deng Meigen(邓梅根), Zang Zhian(张治安), Hu Yongda(胡永 达) et al. J Chin Ceram Soc(硅酸盐学报)[J], 2004, 32 (4): 411

7 Zhang Li(张 莉), Song Jinyan(宋金岩), Zou Jiyan(邹积岩). $J$
Inorg Materials Acta(无机材料学报)[J], 2005, 520(5): 745

8 Reddy R N, Reddy R G. J. Power Sources[J], 2003, 124: 330

9 Li Jun(李 俊), Wang Xianyou(王先友), Huang Qinghua(黄庆华) et al. J Functional Material(功能材料)[J], 2006, 37 (12): 1938

10 Wang Haibin(王海滨), Tian Yanhong(田艳红). J Rare Metals(稀 有金属)[J], 2007, 31 (4):197

11 Chen Ye(陈 野), Zhang Milin(张幂林), Han Ying(韩 莹). $J$ Rare Metals(稀有金属)[J], 2005, 29(1): 30

12 Yang Shuting(杨书延), Liu Yuxia(刘玉霞), Yin Yanhong(尹艳 红). J Inorg Materials Acta(无机材料学报)[J], 2007, 22(5): 62

\title{
Ru-Mn-AC多元复合电极材料的电化学性能
}

\author{
张 莉，宋金岩，邹积岩 \\ (大连理工大学, 辽宁 大连 116024)
}

\begin{abstract}
摘 要: 以提高超级电容器电极材料的电化学性能为目的, 在活性碳粉末中掺入二氧化钓和二氧化锰, 作为电极材料的活性物质, 从而 制备氧化物/活性炭多元复合电极, 组装成超级电容器单元。经循环伏安、恒流充放电和交流阻抗测试的结果表明: 在活性碳粉末中掺 入 $20 \%$ 的二氧化锰时, 复合电极的比容量为 $128 \mathrm{~F} / \mathrm{g}$, 阻抗为 $2.62 \Omega$; 在活性碳粉末中掺入二氧化钉和二氧化锰各 $20 \%$ 时, 多元复合电 极的比容量为 $266 \mathrm{~F} / \mathrm{g}$, 阻抗为 $0.86 \Omega$, 经 1500 次循环充放电后, 电容量几乎无衰减, 得出由活性炭、二氧化钉和二氧化锰构成的多元 复合电极是一种理想的超级电容器电极材料。
\end{abstract}

关键词: 超级电容器; 多元复合电极; 二氧化钉; 二氧化锰; 比电容

作者简介: 张 莉, 女, 1964 年生, 副教授, 大连理工大学电气工程系, 电话: 0411-84707894, E-mail: zhangli379@sohu.com 